\title{
Professionele ethiek in het academisch juridisch onderwijs - Enige inhoudelijke en didactische aanknopingspunten
}

\author{
Special issue on Education in (Professional) Legal Ethics, \\ Emanuel van Dongen \& Jet Tigchelaar (eds.)
}

Emanuel van Dongen \& Jet Tigchelaar*

Abstract

In deze bijdrage bespreken de auteurs inhoudelijke en didactische aanknopingspunten voor de integratie van professionele ethiek in de academische juridische opleiding. Dat gaat wat de auteurs betreft verder dan (enkel) het leren van gedragsregels, maar betreft ook de (kritisch-)ethische reflectie (op de professionele rol) van de jurist en ethische oordeelsvorming. Aanknopingspunten uit rechtstheoretische en onderwijskundige literatuur vragen om een curriculum brede, stapsgewijze, inbedding met passende toetsing. Dit onderwijs dient idealiter een combinatie te zijn van afzonderlijke meta-juridische vakken over recht en ethiek, positiefrechtelijke vakken die ethische elementen bevatten, klinische training en specifieke vakken over beroeps- of professionele ethiek. In dit artikel bespreken de auteurs diverse methoden die kunnen worden gebruikt om het onderwijs vorm te geven en illustreren dit met enkele voorbeelden uit het Utrechts universitair juridisch onderwijs. Actieve participatie, reflectie en - idealiter - eigen ervaringen zijn daarbij van groot belang. Een aantal modellen uit niet-juridische disciplines kan behulpzaam zijn bij het bieden van structuur voor ethische reflectie, voor zover het morele sensitiviteit en morele oordeelsvorming stimuleert. Verscheidene toetsingselementen op het terrein van de ethiek zijn door het curriculum heen nodig. Leeractiviteiten en toetsing kunnen worden opgebouwd in het curriculum van kennis en begrip, naar competenties ten aanzien van ethische dilemma's en moreel oordelen.

* Dr. Emanuel van Dongen is Assistant Professor Private Law at the Molengraaff Institute for Private Law, researcher at the Utrecht Centre for Accountability and Liability Law and the Montaigne Centre for Rule of Law and Administration of Justice, Utrecht School of Law. Dr. Jet Tigchelaar is Assistent Professor Legal Theory at the Institute for Jurisprudence, Constitutional and Administrative Law, researcher at the Utrecht Centre for European Research into Family Law, Utrecht School of Law. 


\section{Inleiding}

Onderwijs in (professionele) ethiek spreekt niet vanzelf. Men zou kunnen denken dat studenten professionele ethiek later, in de beroepspraktijk, wel zullen leren. Toch is het erg zinvol om hier al tijdens de opleiding mee te starten. Onderwijs in (professionele) ethiek is nodig aangezien het belangrijk is dat studenten zich bewust worden van hun toekomstige rol en verantwoordelijkheid in de maatschappij ten behoeve van de rechtsstaat. ${ }^{1}$ Het formele recht biedt geen concreet antwoord op (alle) vragen die zich voordoen in de praktijk. Rechtsregels zijn ook niet voldoende om uitputtend te bepalen wat gebruik dan wel misbruik kan zijn van procesrechtelijke mogelijkheden. Wel bestaan er beroeps- of gedragsregels, maar daarin worden studenten nauwelijks getraind tijdens hun studie. Ook gelden die regels niet voor alle juridische beroepen, terwijl morele vragen en dilemma's zich evengoed kunnen voordoen. Naast goede kennis van het positieve recht, welsprekendheid en analytisch vermogen is het op ethische wijze uitoefenen van het beroep vereist (Van Oostrom-Streep, 2010: 21, 30-31). De hedendaagse 21ste-eeuwse jurist functioneert bovendien in een complexe omgeving, waarin hij of zij moet kunnen omgaan met nieuwe technologieën en ethische dilemma's (zie Mak, 2017). ${ }^{2}$ Kortom, het is belangrijk dat studenten al vroeg in hun carrière inzicht krijgen in ethische problemen en dilemma's in de rechtspraktijk, zoals die worden ondervonden door advocaten, rechters, officieren van justitie, notarissen en andere juristen, vanuit verschillende theoretische benaderingen. En wel zodanig dat ze de praktijk beter beredeneerd en slagvaardiger tegemoet kunnen treden. ${ }^{3}$ In 2018 is daarom bij meerdere docenten van het Departement Rechtsgeleerdheid aan de Universiteit Utrecht, waaronder de auteurs van deze bijdrage, hernieuwde aandacht ontstaan voor het denken over integratie van ethiek in het curriculum en voor het werken aan onderwijsvormen die zijn gericht op professionele ethiek. In deze bijdrage verkennen wij hiervoor enige inhoudelijke en didactische uitgangspunten nader en brengen we enkele aanzetten in het Utrechtse onderwijs ('pilots') daarmee in verband. ${ }^{4}$ Eerst gaan we echter in op het belang van en de effectiviteit van onderwijs in (professionele) ethiek voor rechtenstudenten (par. 2). De inhoudelijke aanknopingspunten voor ethisch onderwijs, inclusief de doelen van onderwijs in beroepsethiek, komen daarna aan de orde (par. 3), gevolgd door de mogelijke (en in Utrecht gerealiseerde) wijzen van integratie van beroepsethiek in het curriculum (par. 4), onderwijsmethoden (par. 5) en toetsing (par. 6). Ten slotte volgt een conclusie (par. 7).

1 Zie recentelijk ook over de (ethische) rol van de juristen, Heineman, Lee \& Wilkins, 2014.

2 Zie over de veranderingen in de juridische professie, de zoektocht naar identiteit van de juridische professie en enkele (voorbeelden van) dilemma's waar men mee te maken heeft, Loth \& Gaakeer, 2017.

3 Zie in het algemeen bijvoorbeeld Kaptein, 2006.

4 De gevolgen van diverse uitgeprobeerde onderwijsvormen ('pilots') voor moreel redeneren van studenten wordt op dit moment gemeten op basis van de Defining Issues Test (DIT), zie Rest e.a., 1999. Resultaten hiervan verschijnen op een later moment. 


\section{Het belang en het nut van onderwijs in professionele ethiek aan de universiteit}

Professionele ethiek betreft 'professies', dat wil zeggen beroepen met een belangrijke maatschappelijke functie (een goede rechtsbedeling, het realiseren van de rechtsstaat), met belangrijke privileges (overheidsrechtspraak, domeinmonopolie), wat om maatschappelijk vertrouwen vraagt en daarom gereguleerd wordt (door wetgeving van staatswege en door de beroepsgroep zelf). ${ }^{5}$ Wij vatten in deze bijdrage professionele ethiek van de jurist ruim op, namelijk als professioneel oordelen en gedrag ten aanzien van ethische kwesties die in relatie tot het recht of de rechtspraktijk spelen. Het is om meerdere redenen belangrijk dat juist aan de universiteit wordt begonnen met onderwijs in (professionele) ethiek voor juristen.

Ten eerste, de universiteit geeft studenten een (laatste) vrije sfeer om zich te beraden op de eigen morele waarden als student en op die van toekomstig jurist zonder dat het schade toebrengt aan een cliënt, henzelf of derden (Menkel-Meadow, 1991: 3-10). Ten tweede, aandacht voor professionele ethiek op de universiteit is van belang om studenten mee te geven en te laten ervaren dat zij als jurist morele keuzes moeten maken, niet alleen als zij met het recht als systeem 'werken', maar ook in hun beroepsuitoefening als jurist. Daarbij vereist het professionele element niet alleen een grondige kennis en begrip van het recht, maar ook een oriëntatie op (professionele) ethiek, waarin steeds onafhankelijkheid (en regelmatig ook moed) een rol speelt (zie ook Van Domselaar, 2017: 909-910). Juist dat professionele element is cruciaal voor het gezag en het vertrouwen in de beroepsgroep en in het recht als institutie (Niemeijer \& Ter Voert, 2005). Het vroeg beginnen met de bevordering van de oriëntatie op een ethisch verantwoorde beroepsuitoefening lijkt, ten derde, een zekere urgentie te hebben, gezien de signalen over (risico's van) niet-integer handelen binnen allerlei juridische beroepsgroepen. ${ }^{6}$

Een vierde reden ziet op de effectiviteit van onderwijs in professionele ethiek aan (jong-)volwassenen. De morele ontwikkeling stopt immers niet bij het bereiken van de meerderjarigheidsleeftijd. Juist tijdens de jonge volwassenheid, i.e. de periode waarin de rechtenstudie gewoonlijk plaatsvindt, veranderen de morele waarden en strategieën van studenten (Rhode, 2007: 1051). Het onderwijzen van ethiek aan juristen dient daarom juist tijdens de academische opleiding te beginnen en kan een krachtige katalysator voor ethische ontwikkeling zijn, ook al is de eigen ervaring met beroepsethische dilemma's nog beperkt. ${ }^{7}$ Onderzoek suggereert dat onderwijs in ethisch handelen inderdaad effect heeft, dat wil zeggen, leidt tot ethischer handelen in de praktijk (zie bijv. Pearce, 1998: 733 e.v.). Er lijkt daar-

5 Zie voor kenmerken van professies (van onder meer juristen) en de rol van ethiek daarin: Noordegraaff \& Siderius, 2016. Zie voor de verbinding van professionele ethiek en rechtsstaat, o.a. Loth, 2011.

6 Zie bijvoorbeeld voor de notaris: Huijgen, 2017; voor het OM: De Meijer, 2019; voor het Openbaar Bestuur: Becker, 2018; voor gerechtsdeurwaarders: Van Dijk, 2018; voor de corporate advocatuur: Van Domselaar, 2017; voor de strafrechtadvocatuur: Fogteloo \& Smolders, 2020.

7 De gebruikelijk gehanteerde methode van casus oplossen is daarvoor echter niet zonder meer geschikt, namelijk voor zover deze methode focust op de juridisch correcte beantwoording van rechtsvragen in het licht van de stand van zaken in wetgeving, rechtspraak en doctrine, zonder daarbij morele of maatschappelijke aspecten mee te nemen in de beantwoording. 
tussen een sterke correlatie te bestaan, hoewel de competentie tot moreel redeneren (moral reasoning) natuurlijk geen garantie is voor (daadwerkelijk) moreel gedrag (moral behaviour) (zie ook Chapman, 2002: 73). Uit onderzoek blijkt bovendien dat goed opgestelde curricula significant kunnen bijdragen aan het verbeteren van moreel redeneren (Rhode, 1992: 46-47; Rhode, 2007: 1051), zeker gezien het gegeven dat morele overtuigingen drastisch veranderen in de vroeg-volwassenheid. ${ }^{8}$ Er wordt wel gesteld dat rechtenstudenten cynisch en kritiekloos worden door hun ervaringen aan de universiteit. Er bestaan indicaties dat cursussen in (professionele) ethiek voor juristen (legal ethics) kunnen helpen om het ongevoelig makende effect van de rechtenstudie op te heffen (Chapman, 2002: 68 e.v.). De rechtenopleiding kan ethische oordeelsvorming beïnvloeden, zowel door het expliciet onderdeel van het onderwijs te maken, alsook door ervoor te zorgen dat moreel redeneren wordt geillustreerd en gewaardeerd door het gehele onderwijsproces (Chapman, 2002: 72). In de volgende paragraaf gaan we in op de vraag welke inhoudelijke aanknopingspunten voor onderwijs in ethiek en moraal reeds bestaan in het academische rechtenonderwijs, dan wel welke gecreëerd zouden kunnen worden. De onderwijsmethoden volgen vervolgens in paragraaf 5 .

\section{Inhoudelijke aanknopingspunten voor ethiek in het rechtenonderwijs}

\subsection{Visies op recht en moraal}

Een groot deel van het curriculum van de rechtenopleiding bestaat uit het aanleren van kennis en begrip van het positieve recht (en uit het aanleren van bepaalde vaardigheden). Daarnaast aandacht hebben voor moraal en ethiek kan kennis en inzicht in het rechtssysteem bevorderen, en beoogt bovendien bij te dragen aan een kritische houding ten aanzien van de ontwikkeling en de werking van het recht en ten opzichte van het eigen (toekomstig) professioneel-juridisch functioneren. De mogelijke inhoudelijke aanknopingspunten voor onderwijs in ethiek voor juristen sluiten goed aan op (vier) visies op de relatie tussen recht en moraal.

De eerste visie is dat het recht niet alleen een systeem van regels is, maar ook rechtsbeginselen en waarden omvat die richtinggevend zijn voor de vorming van recht. ${ }^{9}$ Dit interne perspectief op moraal in het recht corrigeert het rechtspositivisme dat moraal niet kenmerkend vindt voor het recht en dus recht en moraal wil onderscheiden. ${ }^{10}$ Er kan, ten tweede, externe morele kritiek op het recht worden uitgeoefend, bijvoorbeeld op grond van politiek-filosofische theorieën over de democratie, over vrijheid, gelijkheid of op grond van het rechtsstatelijke idee van checks and balances. ${ }^{11}$ Een derde perspectief op recht is dat recht rechtvaardigheid

8 Er bestaan twee perspectieven op moreel redeneren: het ene schrijft morele ontwikkeling toe als gevolg van een rationeel proces, het andere als gevolg van ervaringen (virtue ethics). Virtue kan worden aangeleerd bij volwassenen primair door het uitvoeren van deugdzame, rol-gevoelige handelingen, zie Moliterno, 1991: 95-96.

9 Deze visie wordt ontleend aan Dworkin, 1977: 29-64. Zie ook: Van den Burg, 1997.

10 Een belangrijke vertegenwoordiger hiervan is H.L.A. Hart. Zie Hart, 2012.

11 Hiervan zijn uiteraard vele, vele illustraties te geven, afhankelijk van het onderwerp en invalshoek. Voor democratie en rechtsstaat wordt hier volstaan met Witteveen, Van Klink, \& De Been, 2002. 
moet nastreven, omdat het anders niet zinvol is om over de gebondenheid aan het recht te spreken. Deze (natuurrechtelijke) opvatting van recht betekent dat ethiek, meer specifiek rechtvaardigheid, onlosmakelijk met het recht verbonden is. ${ }^{12}$ Ten slotte is er de rechtsrealistische opvatting van recht, die benadrukt dat het recht wordt gemaakt door mensen met het oog op het maatschappelijk functioneren van het recht. ${ }^{13}$ In deze visie neemt professionele ethiek een vanzelfsprekende plaats in, omdat het gaat over menselijk gedrag en is er oog voor de in de maatschappij levende opvattingen over recht en moraal. In de volgende paragraaf werken we, startend vanuit elk van de zojuist besproken visies op recht en moraal, inhoudelijke aanknopingspunten voor ethiek in het juridisch onderwijs verder uit.

\subsection{Moraal in het recht}

Aansluitend bij de eerste visie op recht en moraal, waarin rechtsbeginselen een belangrijke rol spelen, ligt het voor de hand om in het onderwijs morele legitimaties en onderliggende waarden of idealen van rechtsgebieden en rechtsregels te onderzoeken, het liefst op een bevragende en reflecterende wijze, in plaats van op een stellende manier. Daarbij is het belangrijk dat de ethiek niet verdwijnt achter juridische uitgangspunten, rechtsbeginselen en regels, maar daar een onlosmakelijk onderdeel van is. Bij belangrijke gecodificeerde rechtsbeginselen komt de morele dimensie van het recht bijna vanzelfsprekend aan bod, zoals bij het strafrechtelijk legaliteitsbeginsel. Dat beschermt de morele waarde van handelingsvrijheid juridisch, tenzij de handeling volgens algemeen erkende rechtsbeginselen zo moreel verwerpelijk is, dat het toch tot strafrechtelijke aansprakelijkheid leidt. ${ }^{14}$ Ook beginselen van behoorlijk bestuur en vereisten van redelijkheid en billijkheid in het privaatrecht bevatten duidelijke maar tegelijkertijd nader in te vullen verwijzingen naar hoe de overheid of de burger zich behoort te gedragen ten opzichte van (mede) burgers. Het gaat daarbij om het rekening houden met de belangen van anderen. Dat is niet uitsluitend een juridische plicht, maar een juridische vertaling van een morele plicht. Door studenten over de juridische vertaling na te laten denken, verdiept hun inzicht in de overlap en het verschil tussen juridisch en moreel behoren. ${ }^{15}$ Ook bij moreel en maatschappelijk omstreden kwesties zoals de reikwijdte van de vrijheid van meningsuiting of de risico's van biotechnologie, komt, de morele dimensie bijna vanzelfsprekend aan bod. Ook bij minder duidelijk moreel geladen onderdelen zou het onderzoeken van de onderliggende waarden nuttig zijn, zoals bijvoorbeeld bij bepaalde procedurele voorzieningen, zoals wraking of verjaring.

Kennis van onderliggende morele afwegingen/waarden leidt tot beter begrip van het recht. Dit is van belang als er gekozen moet worden voor de toepasselijkheid van een rechtsregel of voor een interpretatie daarvan in een 'moeilijk geval'.

12 Een klassieker van deze visie is: Radbruch, 1946: 105-108. Zie voor een vertaling hiervan: Mertens, 2012: 76-87.

13 Klassieke vertolkers zijn Frank en Holmes. Zie Frank, 2009; Holmes, 1897: 457-478. Zie recentelijk over de relevantie van het rechtsrealisme voor professionele ethiek: Van Domselaar, 2020.

14 Zie art. 7 lid 2 EVRM.

15 Zie voor de overlap en het verschil in relatie tot het doen van juridisch onderzoek met aandacht voor ethiek: Van der Burg, 2010. 
Onderliggende waarden kunnen dan een houvast geven voor een moreel juiste en juridisch verdedigbare keuze. Deze Dworkiniaanse benadering van het positieve recht maakt studenten vertrouwd met de moraal binnen het positieve recht (Dworkin, 1977: 29-64). Verduidelijking van en beter begrip van deze interne moraal van het recht kan het amorele beeld van het recht als systeem van regels afkomstig van bevoegde rechtsautoriteiten corrigeren en de opvatting van het oplossen van juridische casus als 'slechts' een juridische puzzel bijstellen.

\subsection{Recht en moraal}

Het is ook van belang dat studenten het denken vanuit de dogmatiek tijdens hun studie geregeld loslaten, om zich af te vragen hoe het recht zou moeten zijn. Dit is heel goed verenigbaar met een rechtspositivistische opvatting van recht, waarin morele kritiek op recht mogelijk blijft. Een kritische moraal buiten het recht - te vinden in de eigen morele opvattingen, die van anderen, maar ook ethische theorieën over wat moreel juist of rechtvaardig is - verdient in de tweede plaats nadrukkelijke aandacht. De eigen morele opvattingen lijken echter soms weggeduwd te worden onder het motto: 'het gaat niet om wat je zelf goed of slecht vindt, maar hoe het recht luidt'. Ook kan het wijzen op de rechter, die volgens het geldende recht en niet volgens eigen morele opvattingen recht moet spreken, ertoe leiden dat studenten moreel 'onmondig' worden. Hun articulatie van morele intuïties en oordelen krijgen (te) weinig ruimte, terwijl het heel goed mogelijk is dat zij als jurist te maken krijgen met vragen naar wenselijk recht, met belangenafwegingen en rechtsvragen waarop meerdere antwoorden mogelijk zijn. Bovendien kunnen studenten later met betrekking tot hun eigen professioneel handelen met morele vragen geconfronteerd worden. Belangrijk is dat ze daarmee om kunnen gaan. ${ }^{16}$ In plaats van het eerst aan de universiteit afleren en daarna in de rechtspraktijk weer aanleren van het herkennen van ethische dilemma's en het ontwikkelen van competenties in de uitoefening van een ethisch oordeel, zouden deze juist onderdeel moeten zijn van het academisch onderwijs (zie hierover par. 4).

Hoe legitiem het - rechtspositivistisch geredeneerd - ook is om onderscheid te maken tussen recht en moraal, het risico bestaat dat daardoor ethiek sterk wordt gerelativeerd. Kritisch en onafhankelijk denken over rechterlijke uitspraken of regels, of over het eigen denken, oordelen en handelen, wordt hierdoor niet gestimuleerd. Dit terwijl dat juist heel belangrijke waarden zijn voor een academisch opgeleidejurist, die veelal een publieke functie zal (gaan) vervullen en in die hoedanigheid zal (gaan) bijdragen aan de verwerkelijking van de rechtsstaat. Kennis van ethische theorieën, zoals de deontologie en het consequentialisme, kunnen bovendien bijdragen aan het kritisch beoordelen van de ontwikkeling van het recht. Zo kan de categorische imperatief uit Kants deontologie helpen om te beoordelen of de uitgangspunten van regels, beslissingen of gedrag aanvaardbaar kunnen zijn voor ie-

16 Zie o.a. Van Domselaar, die het ethisch minimalisme thematiseert in Van Domselaar, 2017: 902910. Zie verder Fogteloo \& Smolders, 2020, waarin meerdere voorbeelden staan van strafpleiters en bedrijfsadvocaten die ofwel morele vragen niet herkennen of die bewust buiten beeld laten. Zie ook voor het 'weg'redeneren van morele kwesties: De Groot-van Leeuwen \& Schuyt, 1992. Zie voor een toegenomen aandacht voor ethiek in de opleiding voor de commerciële advocatuur: Fogteloo \& Smolders, 2021. 
dereen, ook als degene die de regel maakt, beslissingen neemt of handelt, daar zelf aan onderworpen zou worden. Het consequentialisme van het utilisme bijvoorbeeld, wijst erop dat voor het oordeel wat het juiste handelen is, de gevolgen voor het algemeen welzijn van belang zijn.

\subsection{Rechtvaardig recht}

Wanneer echter - ten derde - wordt uitgegaan van een natuurrechtelijke opvatting dat recht en moraal niet te scheiden zijn, omdat recht niet goed denkbaar is, als het geen rechtvaardigheid nastreeft, dan wordt ethiek nadrukkelijk verbonden aan het recht. Studenten moeten wel meekrijgen dat opvattingen over moraal en rechtvaardigheid weliswaar kunnen verschillen, maar niet uitsluitend subjectief gevormd worden en 'dus' niet besproken hoeven te worden. Voor een meer 'objectief' beredeneerd en bediscussieerde benadering, ligt het voor de hand politiek-filosofische theorieën over een rechtvaardige samenleving, alsook ethische theorieën over juist handelen te bespreken. Dit gebeurt in de rechtenopleidingen ook wel, het duidelijkste wellicht in het kader van liberale of liberaal-egalitaire contracttheorieën, bijvoorbeeld die van Locke of Rawls, alsook in verband met mensenrechten. Wil dit echter beklijven als een relevante benadering van het recht, dan zal de actuele waarde moeten worden belicht en is het zinvol om mensenrechten niet alleen als een soort internationale wetgeving, maar ook als universele morele maatstaven te bespreken en de grondslagen ervan te bediscussiëren. ${ }^{17}$

Cruciaal voor het onderwijs over de relatie tussen recht en moraal, is dat studenten steeds gestimuleerd worden om voor zichzelf na te gaan welke theoretische benadering (zoals genoemd in deze paragrafen) van recht, rechtvaardigheid en ethiek hen meer aanspreekt dan een andere en welke redenen zij daarvoor hebben. Hierdoor wordt de bespreking van recht, moraal en ethiek niet alleen een theoretische - academische - exercitie, maar een benadering, waartoe studenten zich bewuster kunnen verhouden en zich nadrukkelijker mee verbinden. ${ }^{18}$

\subsection{Professionele ethiek}

Aandacht voor, ten vierde, professionele ethiek sluit sterk aan bij de rechtsrealistische benadering dat recht door menselijk handelen wordt gemaakt en moet aansluiten bij maatschappelijke behoeften. ${ }^{19}$ Deze benadering is gericht op het realiseren van recht in de praktijk, door bijvoorbeeld wetgevers, bestuurders en rechters, maar ook door (andere) praktijkjuristen. De deugd- en zorgethiek ${ }^{20}$ geven voor het vervullen van deze rollen ethische handvatten. (Wat maakt een goed jurist? Welke morele verantwoordelijkheid heeft een jurist in de concrete uitoefening van diens publieke professie in de rechtsstaat?) Ook rechtsbeginselen, kernwaarden en gedragsregels gelden als ethische bakens voor deze functies. Een rechter die volgens het recht geacht wordt onafhankelijk en onpartijdig te zijn, moet kunnen luisteren, heeft soms ook moed nodig om bestuur of wetgever terug te fluiten, alsook praktiwordt doorgaans Gilligan, 1982 als basis genoemd. 
sche wijsheid. Het onderzoeken van en oefenen met deze deugden legt de basis voor een goede jurist en burger. ${ }^{21}$ Met studenten kan worden besproken met welke factoren een advocaat rekening zou moeten houden bij het nemen van procedureel strategische keuzen: gaat het om de juridische vertaling van de behoeften van de cliënt of ook om diens belastbaarheid of persoonlijk welzijn op de lange termijn?

Professionele kernwaarden en rolopvattingen van de togadrager geven eveneens richting aan de ontwikkeling van een professionele ethiek (zie hiervoor De Wolff, 2018; Bauw e.a., 2019; De Wolff, 2020). Het onderzoeken van deze (soms conflicterende) kernwaarden, zowel in relatie tot de latere professionele rol, als tot de huidige rol als student, kan de morele attitude van studenten versterken. ${ }^{22}$ Integriteit, bijvoorbeeld, is ook voor studenten van belang: hoe gaan zij om met verleidingen van fraude en plagiaat, bij henzelf of medestudenten? En hoe kan er tegen de partijdige behartiging van gerechtvaardigde belangen van een cliënt aangekeken worden? Spelen daar ook belangen van andere betrokkenen (zoals slachtoffers) een rol, het functioneren van het rechtssysteem of bredere maatschappelijke belangen, zoals mensenrechten of duurzaamheid, of is dat te veel gevraagd? ${ }^{23}$

De gedachte dat kennis van de professionele gedragsregels voldoende is voor duidelijke en uitvoerige begeleiding voor alle zich voordoende kwesties, onderschrijven wij niet. Een dieper begrip van, en voortdurende discussie over, de verantwoordelijkheid van de juridische professional om moeilijke ethische beslissingen te nemen in een diversiteit aan situaties, is nodig. Het publieke belang van een goede rechtsbedeling (de - vervallen - zesde kernwaarde van de advocaat) in de rechtsstaat noopt daartoe. ${ }^{24}$ Professionele standaarden zijn onmisbaar als uitdrukking van de publieke verantwoordelijkheid van de professie en als richtsnoer voor de individuele professional. Het enkel focussen op de professionele codes kan echter een moraliteit creëren, die er primair op gericht is om binnen de grenzen van de regels te blijven en niet gericht is op een algemeen gerechtvaardigde handelwijze. Deze benadering is eveneens te minimalistisch, als het afstand doet van een deugdethiek. Deze benadering staat het individu toe om de eigen morele antenne en ervaringen in te brengen met betrekking tot de juiste uitleg en prioritering van professionele (kern)waarden. Een combinatie van regels, waarden en deugden moet dus aan de orde worden gesteld in het onderwijs om hun onderlinge verwevenheid te onthullen. De persoonlijke ervaringen en waarden dienen te worden geïntegreerd. Aangezien ethische oordeelsvorming noopt tot een reflectieve deliberatie en rechtvaardiging voor (persoonlijke) keuzes, moet het omgaan met persoonlijke waarden in de professionele rol eerder worden benadrukt dan weggeredeneerd.

21 De Giving Voice to Values benadering (van Gentili, 2010) benadrukt het handelingsaspect: het gaat verder dan oordelen wat juist is en oefent hoe juist te handelen.

22 Kernwaarden laten zien dat er een hoger belang is dat dient te worden beschermd met het oog op het vertrouwen dat men in de professie mag hebben, maar ook voor het vertrouwen in een individuele togadrager. Kernwaarden geven aan wat wenselijk (ethisch) gedrag is; normen geven grenzen daarvan aan en geven aan waar onwenselijk (onethisch) gedrag begint. Zie Soeharno, 2014: 3-6. Zie ook Mackor, 2014: 6-9.

23 Deze vragen gaan nadrukkelijk niet alleen over professionele ethiek als juridische verplichtingen, die tuchtrechtelijk kunnen worden afgedwongen, maar ook over het verbinden van de professionele ethiek met een persoonlijke ethiek van morele verantwoordelijkheden. Zie over 'de zesde kernwaarde' onder meer De Wolff, 2018: 6. 


\subsection{Inhoudelijke benaderingen en leerdoelen}

De vraag naar doelen van onderwijs in professionele ethiek voor juristen is relevant voor de te ondernemen onderwijsactiviteiten. Onderwijsactiviteiten dienen immers afgesteld te worden op de leerdoelen. ${ }^{25}$ De zojuist beschreven vierde inhoudelijke benadering van professionele ethiek sluit goed aan op de leerdoelen die Robertson verbindt aan onderwijs in legal ethics. Deze omvatten allereerst begrip van de maatschappelijke rol van de jurist in de rechtsstaat en het zich bewust zijn van de ethische verantwoordelijkheid die daaruit voortvloeit, begrip van de rechtvaardiging van de bijzondere bevoegdheden die verbonden zijn aan juridische professies en kennis van professionele standaarden en verantwoordelijkheden. Maar het gaat ook om een kritische benadering van de vraag in hoeverre de juridische regulering een moreel verantwoorde juridische praktijk mogelijk maakt en in hoeverre van praktijkjuristen gevraagd mag worden om moreel autonoom te zijn en ethisch verantwoord te besluiten. Daarvoor moet, in de lijn van de deugd- en zorgethiek, het vermogen ontwikkeld worden om situaties te herkennen waarin ethische kwesties zich kunnen voordoen en de feitelijke complicaties die ethisch gedrag lastig maken (Robertson, 2009: 70-71). Boon legt een iets ander accent, als hij de eindtermen van onderwijs in professionele ethiek formuleert: enerzijds zou het onderwijs de uitoefening en ideologie van de professie moeten ondersteunen, anderzijds zou het onderwijs het ethisch gedrag (weerstand bieden aan onethische praktijkculturen) en oordeelsvorming moeten versterken (Boon, 2002: 54 e.v.). Deze eindtermen zijn eveneens in lijn met onze visie op het onderwijs in professionele ethiek. Allereerst moet dit onderwijs aansluiten op normering van de professie. Daarvoor is kennis, begrip en inzicht nodig in de betekenis van kernwaarden en andere beroepscodes. Daarnaast dienen studenten te reflecteren op professioneel handelen, om zo een professionele houding te bevorderen. Ten slotte dienen ze zich bewust te zijn van de verantwoordelijkheden die voortvloeien uit de juridische professie in de context van de rechtsstaat. Het versterken van ethische oordeelsvorming sluit eveneens aan op de andere - minder aan de concrete uitoefening van de professie verbonden, maar daarin wel doorwerkende - inhoudelijke aanknopingspunten over de verhouding tussen recht en moraal.

Het zou een grote meerwaarde zijn als het (meer) vanzelfsprekend wordt om studenten uit te dagen om verder te kijken dan kennis en begrip van de techniek en het systeem van een rechtsgebied. Dit kan door achterliggende morele waarden er nadrukkelijker bij te betrekken en hen te bevragen over welke eigen morele opvatting zij hierover hebben, wat volgens hen bijdraagt aan rechtvaardig recht en wat dit kan betekenen voor hun eigen oordeelsvorming en gedrag. ${ }^{26}$ Gribnau thematiseert het belang van deze meerwaarde kernachtig: 'Fiscalisten voelen zich vaak ongemakkelijk zodra het over fiscale ethiek gaat. De fair share-discussie is daar een

25 Cf. Biggs' theorie van constructive alignment, zie Biggs \& Tang, 2011.

26 Ahsmann bepleit redeneren op basis van waarden en reflecteren op morele dilemma's uit de praktijk van het recht, zodat ze tot een goede oordeelsvorming kunnen komen. Zie Ahsmann, 2016. Wat betreft redeneren op basis van waarden is interessant in dat verband de Giving Voice to Values methodology, i.e. om tijdens het onderwijs daadwerkelijk het formuleren van argumenten te oefenen die gericht zijn op het effectief ethisch handelen. Zie o.a. Gentili, 2010; Ferris, 2015: 252. 
voorbeeld van. Ethiek is echter inherent aan het belastingrecht - dus ook het gebruik daarvan. ${ }^{27}$

\section{Integratie in het curriculum}

De volgende vraag is op welke wijze onderwijs in professionele ethiek kan worden geïntegreerd in het curriculum. In abstracte zin kan men drie manieren van onderwijs in professionele ethiek onderscheiden:

- rechtstreeks (directly; exclusief over beroeps- of professionele ethiek, op een thema waar studenten al onderwijs over hebben gehad);

- bij diverse cursussen wanneer ethische vragen opkomen (pervasively); ${ }^{28}$

- in een klinische setting (praktische mogelijkheid om te werken aan echte of gesimuleerde juridische problemen onder supervisie en met begeleiding).

Een combinatie van deze manieren van onderwijs en het doorvoeren van de onderliggende gedachten achter onderwijs in professionele ethiek in het gehele curriculum lijkt het meest ideaal. Korte introducties in ethiek zijn onvoldoende om een blijvend verschil te maken in ethische oordeelsvorming. Uit onderzoek blijkt dat het sterkste effect wordt waargenomen bij cursussen die tussen vier en twaalf weken duren (zie Rest, 1986). Een enkel vak inhoudende een bespreking van de regels over professioneel gedrag, zoals in de USA vaak het geval is, leidt echter veelal tot een minimalistische benadering. Het gaat dan eigenlijk om juridische ethiek, zonder het (daadwerkelijk) gebruik van ethiek, en het laat de jurist vaak achter zonder de grondslagen voor reflecterend oordeel (reflective judgment) (Rhode, 2003: 340). In Ontario (Canada) wordt er meestal voor gekozen om ethiek niet als een apart vak aan te bieden, maar als onderdeel van meerdere vakken (Pitel, 2005: 592 e.v. zie ook Edwards, 1992: 74). Dit sluit aan bij ons idee dat recht en ethiek niet alleen aan de orde moet komen in meta-juridische vakken, maar dat er voor een goed begrip van het recht en een kritisch perspectief op het recht met het oog op het latere (publieke) functioneren als jurist ook systematisch aandacht aan moet worden besteed in positiefrechtelijke vakken.

Idealiter wordt (beroeps- of professionele) ethiek vormgegeven als een 'vertical subject' throughout the curriculum (Robertson, 2004: 7, als een onderwijskundig continuüm vanaf beginfase tot voortdurende professionele ontwikkeling. Dit maakt een incrementele leercurve en leerdoelen die daarop zijn afgestemd mogelijk. Het leren van de regels, theorieën en argumenten met betrekking tot moreel oordelen, ethisch en professioneel gedrag is een proces dat al moet worden gestart tijdens de juridische opleiding. Zo zorgen we ervoor dat onze studenten competente juristen worden, die niet alleen oog hebben voor de juridisch correcte, maar ook voor de

27 Gribnau, 2017: 1. Het door Gribnau geconstateerde ongemak, kan gemakkelijk leiden tot het uitschakelen van het geweten, hetgeen allerlei risico's heeft voor de jurist als persoon (vervreemding van de eigen waarden), iemands professioneel functioneren (gezien diens integriteit en onafhankelijkheid), het functioneren van de beroepsgroep (verharding, amorele beroepscultuur), en het recht in de context van de samenleving. Zie ook De Wolff, 2018: 10-11.

Zie bijvoorbeeld Robertson, 2009: 59 e.v. 
moreel aanvaardbare oplossing. ${ }^{29}$ Dit sluit goed aan bij de Utrechtse benadering van 'recht in context', waarin naast de rechtswetenschappelijke context van het recht ook aandacht is voor de maatschappelijke en ethische context. Voor het plaatsen van het (positieve) recht in een bredere context is reflectie nodig en het inzicht dat het recht aanleiding geeft tot verschillende interpretaties. Daarvoor moeten keuzes worden gemaakt waarbij argumenten van diverse aard een rol spelen, waaronder ook ethische overwegingen (zie ook Van Klink, De Vries \& Bleeker, 2017: 916-922).

Tijdens de opleiding dient de nadruk in het curriculum zich te verplaatsen van descriptie naar reflectie en een kritische houding (zie ook Boon, 2002: 34 e.v.) Bij een stapsgewijze opbouw in het curriculum moet het niveau in leerdoelen voor ethiek toenemen in complexiteit (Robertson, 2005: 237-239; Robertson, 2009: 63). Uit (online beschikbare) cursusbeschrijvingen blijkt dat er op een aantal Nederlandse universiteiten al in een vroeg stadium van de rechtenstudie een introductie van (professionele) ethiek is, die later dieper wordt uitgewerkt. ${ }^{30}$ Dit is een interessante gedachte, en past bij het idee dat de ontwikkeling van ethische wortels een langdurig proces is, vooral in relatie tot doelstellingen die zijn gerelateerd aan motivatie en karakter (Boon, 2002: 64) ${ }^{31}$ Het onderwijs kan de studenten hierin ondersteunen.

Bij de integratie van professionele ethiek in het curriculum zijn drie benaderingen te onderscheiden, van smaller naar breder, die effect hebben op de plaats van professionele ethiek in het curriculum. De eerste benadering (de zogenaamde 'knowledge of professional rules' approach) ziet er typisch uit als een afzonderlijk vak, terwijl er elders in het curriculum weinig of geen tijd wordt ingeruimd voor beroepsethiek. Daarbij ligt de nadruk op professionele gedragsregels en hun toepassing. In de tweede benadering (de zogenaamde 'ethical dilemma' approach) ligt de nadruk op verkrijgen van skills in: a) het herkennen, en b) het oplossen van ethische dilemma's. Dit leidt niet per se tot een curriculumbrede benadering, al is dat wel mogelijk, en is ook ideaal voor klinische cursussen.

In de derde benadering (de zogenaamde 'judgement' approach) ligt de nadruk op de discretionaire rol van de juridische professional, de noodzaak van het maken van keuzes, onder andere in ethische kwesties, als integraal deel van de latere praktijk. De nadruk ligt hierbij op het proces van beslissen wanneer men geconfronteerd wordt met dilemma's en het ontwikkelen van competenties in de uitoefening van een ethisch oordeel. Aangezien ethische kwesties zich kunnen voordoen bij elk onderwerp, ligt een zo breed mogelijke implementatie in het curriculum voor de hand (ontleend aan Robertson, 2004). De tweede en vooral ook de derde benadering zijn daarom belangrijker en interessanter dan de eerste.

Bovendien kan het nadenken over kernwaarden en leren over ethische gedragsregels een positief effect hebben op de persoonlijke ontwikkeling van studenten (Bildung).

30 Een argument voor de implementatie is een eerstejaars cursus professionele ethiek, waardoor studenten ook meer geïnteresseerd zouden kunnen worden in het volgen van die optionele keuzevakken voor het hogere jaar.

31 Motivatie en karakter zijn twee componenten van moreel gedrag, naast morele gevoeligheid (het bewustzijn van morele dimensies van een bepaalde situatie); morele beoordeling (ethisch redeneren); zie Rest \& Narváez, 1994. 
Niet alleen voor de inhoud, maar ook voor het niveau van leren (soort begrip/ kennis), heeft de keuze voor één of meerdere van de drie zojuist besproken benaderingen gevolgen. De hoogste niveaus van leren zijn bereikbaar via de derde methode. Dit is dan ook de methode die wij voorstaan. ${ }^{32}$ Indien de competentie van het uitoefenen van een ethisch oordeel centraal staat, dient deze competentie stapsgewijs ontwikkeld te worden, dus op meerdere momenten in het curriculum. Zo worden de eerder besproken theoretische en/of ethische benaderingen gewoonlijk besproken bij meta-juridische, rechtstheoretische vakken. Ethiek dient echter niet enkel in de rechtstheoretische vakken aan bod te komen. Elk positiefrechtelijk vak leent zich namelijk voor de behandeling van de achterliggende waarden van het rechtsgebied of leerstuk. Ethische en politiek-filosofische theorieën op deelterreinen van het recht of ten aanzien van de rechtsstaat, houden juristen scherp op (on) wenselijke ontwikkelingen van het recht en 'op een goede rechtsbedeling'. Een goed onderbouwde kritische benadering van de vraag hoe een leerstuk van het recht zou moeten zijn is niet gemakkelijk, zeker niet voor jonge mensen. Deze kost ontwikkelingstijd, maar dat neemt niet weg dat studenten vanaf het begin van hun studie al wel getraind kunnen worden in kritisch en onafhankelijk denken (Cottrell, 2017).

\section{Onderwijsmethoden voor het vormgeven van ethiekonderwijs}

\subsection{Diverse onderwijsmethoden}

Internationaal wordt er meer geschreven over de methoden van juridisch ethiekonderwijs dan in Nederlandse literatuur. De hoorcollegevorm en werkvormen en discussies op basis van hypothetische casus en realistische rechtszaken zijn nuttig om kennis en begrip van (ethische theorieën over) recht te onderwijzen (zie par. 3) en om een aanzet te geven voor reflectie en moreel redeneren (zie par. 4). Ter inspiratie en geïllustreerd met Utrechtse voorbeelden, bespreken we hierna werkvormen die voor een deel door gespreksvormen het moreel redeneren activeren en stimuleren (zie hieronder par. 5.1.3 en 5.1.6), voor een deel gericht zijn op het aanspreken van de persoonlijke c.q. professionele betrokkenheid van studenten bij morele problemen (par. 5.1.1, 5.1.2, 5.1.5) of creativiteit (par. 5.1.4) stimuleren. Deze werkvormen hebben de potentie om meer bij te dragen aan moreel redeneren dan de traditionele werkvormen, zoals we op basis van de bestaande literatuur over deze werkvormen ook zullen beschrijven.

\subsubsection{Problem method}

Professionele ethiek wordt het best aangeleerd door middel van problemen en dilemma's die zich voordoen in de praktijk. Anders dan bij de klinische methode, waar de focus vaak ligt op de belangen van de cliënten, focust de zogenaamde problem method op de student en ligt de nadruk op de soort persoon en professional 
die de student later zal worden (Morgan, 1998: 409 e.v., in het bijzonder p. 417). Deze lijkt sterk op een professionele ethiek als deugdethiek. In deze methode worden studenten in hypothetische situaties in de rol van de latere juridische professional geplaatst en moeten zij met een praktisch plan, inclusief alternatieve wijzen van handelen, komen voor de oplossing van het probleem. De methode kan op twee manieren bijdragen aan het aanleren van een professionele houding door studenten:

- het vereist meer verantwoordelijkheid van de student en actievere participatie (discussies centreren rond studenten, die zichzelf moeten visualiseren in praktijksituaties);

- het stelt de docent in staat om een rolmodel te zijn (wat een positieve impact kan hebben op rechtenstudenten) (zie ook Miller, 2005: 365 e.v.) ${ }^{33}$ en te onderwijzen door zelf het goede voorbeeld te geven (to teach by example; zie Ogden, 1984: 654 e.v.).

Daarmee zijn we bij een tweede werkvorm aangekomen.

\subsubsection{Storytelling en narratieven}

Het fungeren als rolmodel door de docent (teaching by example) als deel van het modelleer- en identiteitsvormingsproces is het efficiëntst als het dicht bij de rol komt die moet worden aangeleerd (Moliterno, 1991: 112) ${ }^{34}$ Het kan gebeuren ofwel door direct te werken met een juridisch professional (live role modelling) - bijvoorbeeld in het kader van een stage - ofwel door middel van storytelling. Storytelling is altijd een effectieve onderwijstool, die, wanneer geïntegreerd in het universitaire onderwijs, in feite elementen van het oude apprentice-systeem overneemt, al werkt het direct werken met een juridisch professional nog beter (Moliterno, 1991: 112-113). ${ }^{35}$ Door storytelling geef je een voorbeeld op basis van eigen ervaringen van de professional. In het Utrechtse master-onderwijs werd in de afgelopen jaren in het kader van het master honours onderwijs door docenten eigen ervaringen (als advocaat) geïntegreerd in het onderwijs in professionele ethiek. Hierin stonden diverse dilemma's centraal. Ook in het Utrechtse bachelor honours-onderwijs (het 'Utrecht Law College') is in 2020 bij storytelling aangesloten. Tweede- en derdejaars honours-studenten konden zich opgeven voor een module 'professionele ethiek', een lezingencyclus, waarin gastsprekers uit de wetenschap en de praktijk morele vraagstukken uit de juridische professionele praktijk belicht-

Volgens Miller is naast de inhoud en de methode ook gepast gedrag nodig van degene die het gezag heeft (de docent) tegenover degenen die dat niet hebben (de studenten). Op dit punt is de docent 'de (praktijk)jurist' en de rechtenstudent 'een cliënt'. De gebruikte onderwijsmethode bepaalt voor een groot deel de visie die studenten als jurist gaan aannemen.

34 De implicatie hiervan is, schrijft hij, dat ideeën over professioneel gedrag verzameld van praktiserende advocaten gretig zullen worden opgepakt en nagevolgd door studenten. Hij baseert zich op Watson, 1975: 251. Het lijkt dus aangewezen dat docenten die professionele ethiek onderwijzen enige praktijkervaring hebben of tegelijkertijd praktiseren. De juridisch professional moet (vooral in dat laatste geval) dan wel onbevangen kunnen spreken over ethische dilemma's. Er kan hierbij echter wel een belangenconflict optreden (academische openheid versus commerciële afscherming) en ook kan een geheimhoudingsplicht de praktijkverhalen afvlakken.

35 In de master-fase van de studie kunnen gerenommeerde professionals ingezet worden bij de diverse positiefrechtelijke vakken. 
ten. Dit gebeurde deels op grond van eigen ervaringen, deels werden morele dilemma's verbonden met ethische theorieën. Ook kernwaarden, gekoppeld aan rolopvattingen werden belicht, alsook algemenere waarden en deugden die verbonden zijn aan goed bestuur en burgerschap. De inbreng van verhalen van enkele strafrechtadvocaten, die hun beroepsuitoefening nadrukkelijk in lijn brachten met hun persoonlijke waarden en daarbij bijna exemplarisch zorgethisch te werk gingen, werd door studenten zeer gewaardeerd als rolvoorbeeld. ${ }^{36}$ Het gebruik van storytelling ligt dicht tegen het gebruik van narratieven aan, waarin het gaat om het gebruik van materialen (verhalen in films, toneelstukken enz.) van andere praktiserende juristen. Het integreren van narratieven in het onderwijs kan op twee manieren invloed hebben: ze hebben de potentie van narratieve interesse; en ze hebben invloed op wat mensen in het leven als haalbaar beschouwen (Ferris, 2015: 230). Narratieven uit het leven van gerenommeerde advocaten zijn bruikbaar (Bundy, 1995: 19 e.v.). Behalve voor historische figuren, kan er ook gekozen worden voor personen die betrokken zijn geweest bij recentere processen of zaken, of voor fictieve verslagen van juridische educatie en juridische praktijken (Ferris, 2015: 229-230). In een van de Utrechtse master-programma's wordt een caput gegeven waarin studenten reflecties moeten schrijven op basis van hypothetische of narratieve voorbeelden. ${ }^{37}$

\subsubsection{Dialoog}

Deze methode is gebaseerd op gesprek, dialoog, waarbij zoveel mogelijk wordt gezegd over de praktische en existentiële problemen waarmee juristen worden geconfronteerd als ze proberen het juiste te zeggen en te doen. Bij de dialoog wordt een gezamenlijke poging gedaan om te articuleren wat we zullen doen als morele actoren in de wereld (moreel discours). Het idee van professionele verantwoordelijkheid ligt dichter bij het idee van het bijwonen, bewust maken en spelen met de nuances en subtiliteiten van morele waarden dan bij het routinematig leren van ethische regels en principes. Bij deze methode ligt de focus op ethiek als conversatie, de focus ligt op het proces en de interactie; de manier van samenkomen en engageren in gesprek beïnvloedt na verloop van tijd ons gevoel van moraliteit (Elkins, 1986: 265 e.v.). Dialoog is inderdaad een effectieve wijze om aannames, misvattingen en fouten bloot te leggen en om de gewoonte van ethische besluitvorming te ontwikkelen. Andermans ervaringen vormen daarbij potentieel een nuttig middel om te leren, al zijn eigen ervaringen nog beter, want de lessen die je daaruit trekt zijn namelijk meer onmiddellijk, echt en 'dieper' (Boon, 2002: 34 e.v., verwijzend naar Kupfer, 1996: 33 e.v.).

\subsubsection{Storyboards}

Een creatieve werkvorm is het gebruik van door studenten gemaakte storyboards. Deze onlinegroepscreaties van storyboards en scripts vormen een authentieke methode voor het leren van beroepsethiek. Het is een out of the box-werkwijze, die bij

37 Caput Philosophy and Ethics of International Law, gedoceerd door dr. L. Henderson. 
kan dragen aan de IT-vaardigheden van studenten. Collbran en Gilding beschrijven een vak waarin studenten een ethisch probleem naar keuze, met assessment die learner-focused was (in plaats van teacher-focused). Dit was ontworpen om deep-learning approaches te bevorderen door nieuwe informatie te relateren aan bestaande kennis en persoonlijke ervaring, en door theoretische ideeën te koppelen aan dagelijkse ervaringen. Deze werkwijze leidt tot een verschuiving van verantwoordelijkheid van docent naar student, en tracht vaardigheden van studenten te ontwikkelen via diverse dimensies: onafhankelijkheid, verantwoordelijkheid, creativiteit enzovoort. De opdracht was het maken van een storyboard, inclusief een titel en leerdoelen voor de animatie, aangevuld met door de studenten opgestelde meerkeuzevragen met goede en foute antwoorden. Blijkens het door Collbran en Gilding uitgevoerde onderzoek leidde deze creatieve taak inderdaad tot analyses en discussies van ethische kwesties in groepsverband (zie Collbran \& Gilding, 2014: 296 e.v.).

\subsubsection{Role-sensitive representation activities en experiential learning}

Hier draait het om het leren van ethiek en moreel gedrag middels ervaringen. Hoe kan dat worden vormgegeven? Dit kan bijvoorbeeld door middel van het gebruik van literatuur, populaire films en televisie, of door ervaringsgerichte oefeningen (studenten blootstellen aan ethische dilemma's) die complex en realistisch zijn (groepswerk) (zie ook Lerner, 2004: 643 e.v.). Experiential teaching kan de ontwikkeling van moreel redeneren aanzienlijk bevorderen (zie Hartwell, 1995: 505-540). Het biedt de mogelijkheid om de diverse perspectieven te observeren en te ervaren (rechtsbeoefenaar, cliënt, wederpartij enz.) (Nicolae, 2015: 237 e.v.). Dit kan of door middel van een rollenspel, clinics met cliënten, externe stages of met behulp van simulaties (zie bijv. Green, 1998: 357-392). Learning by doing (of door imitatie) draagt bij aan morele oordeelsvorming. ${ }^{38}$ Er bestaat eenstemmigheid in de literatuur over dat de klinische cursussen het meest effectief zijn (Boon, 2002: 34 e.v.; Rhode, 2007: 1052).

De beste manier om ethisch oordelen te verbeteren is in het algemeen door betrokkenheid bij echte problemen, waarbij echte cliënten betrokken zijn. Ethische dilemma's zijn dan inherent aan het werken met echte cliënten (Duncan, 2015: 73). Vaak wordt aangegeven dat simulaties een second best optie zijn (een Utrechts voorbeeld beschrijven we nog). ${ }^{39}$ In plaats van aan studenten te vragen wat ze in een bepaalde situatie zouden doen, worden ze in die situatie geplaatst en moeten ze handelen, met de mogelijkheid om na te denken. Dit biedt een veel betere basis voor het ontwikkelen van een leerspiraal (Kolb, 1984). Clinics is zowel 'taking responsibility for others in society' als 'making non-hypothetical, irreversible moral choices' (en daarmee voldoen clinics aan twee van Kohlbergs criteria voor de ontwikkeling

38 Een voorbeeld van experiential learning kan worden gevonden in Bensinger-Liebman, 1995: 73-86. Een van de interessantste en succesvolste aspecten van de cursus is de betrokkenheid van praktiserende advocaten bij zowel de ontwerpfase als bij de onderwijsfase.

39 Zie ook Bundy, 1995, die schrijft over diverse soorten simulaties, waaronder een onderhandelingssimulatie. Ethiek kan ook worden gekoppeld aan training in kritische professionele vaardigheden, zoals de ontwikkeling van interview-, counseling- en onderhandelingsvaardigheden. Zie ook Burns, 1996: 684-703. 
van moreel redeneren) (Chapman, 2002: 83). Clinics en stages kunnen het soort ervaringskennis en geleide reflectie bieden, die bevorderlijk zijn voor adult learning, in het bijzonder ten aanzien van ethische kwesties (Rhode, 2007: 1052). In 2021 is de Utrecht Law Clinic van start gegaan. ${ }^{40}$ Dit is een samenwerking tussen de Universiteit Utrecht en Van Benthem \& Keulen. ${ }^{41}$ De klinische ervaring die studenten hierbij opdoen kan de ontwikkeling van ethische professionaliteit bevorderen (met name de morele gevoeligheid (moral sensitivity); zie Ferris, 2015: ch. 6) ${ }^{42}$ Kritische reflectie kan worden bevorderd door kritische evaluatie/begeleiding door anderen. Dit kan studenten helpen om life-long learning skills van de reflectieve professional ontwikkelen (Nicholson, 2010: 171 e.v., 174). Ook kunnen studenten tijdens stages een journal bijhouden over hun ervaringen, te beoordelen door de docent. Die ervaringen kunnen ze inbrengen in een kleine groep op de universiteit. De stage verrijkt de simulatie-ervaringen op de universiteit; de simulaties daarentegen, geven de studenten het analytische kader waarin ze hun stageactiviteiten kunnen ervaren en evalueren (Moliterno, 1996: 67 e.v.). Ook kan role-playing een uitstekende methode zijn om professionele rollen aan te leren, zoals de advocaat, juridisch adviseur, bemiddelende partij enzovoort (zie ook Schrag, 2009: 35-57). Dit houdt in dat studenten gevraagd wordt iets uit te voeren, te schrijven, over iets te onderhandelen etc. in de hoedanigheid van een bepaalde rol.

Voor derdejaars Utrechtse honours-studenten is inmiddels een ethieklijn geïntegreerd in een complex, maatschappelijk actueel, juridische simulatiespel over een start-up, met verschillende juridische rollen (zoals een notaris, bedrijfsjurist, arbeidsrechtadvocaat enz.). ${ }^{43}$ Studenten wordt nadrukkelijk gevraagd om hun rol en beroepsproduct juridisch én ethisch te benaderen. In de ethieklijn worden studenten geconfronteerd met conflicten tussen verschillende ethische theorieën (het utilisme, deontologie en deugdethiek) en soorten waarden en standaarden (zoals persoonlijke, professionele, institutionele en maatschappelijke c.q. rechtsstatelijke waarden en standaarden).

\subsubsection{Andere niet-juridische methoden}

Een aantal andere methoden die afkomstig zijn uit niet-juridische disciplines kunnen ook behulpzaam zijn bij het vormgeven van het ethiekonderwijs aan juristen om zo morele beraadslaging te ontwikkelen. De eerste methode is het 'Utrechts stappenplan', afkomstig van het Utrechtse Ethiek Instituut. Het is een gestructureerd hulpmiddel voor ethische reflectie op individueel of op groepsniveau om tot een verantwoorde keuze of handeling te komen voor concrete dilemma's (Bolt, 2010: 17-32. Zie ook Bolt e.a., 2015). Deze methode onderscheidt de (vijf) fasen van verkenning van een casus: explicitering (van onder meer de morele vraag, mogelijke handelingen en ontbrekende feitelijke informatie); analyse (van betrokkenen en hun perspectieven, alsook relevante argumenten voor de beantwoording van de

40 Zie https://www.uu.nl/samenwerken/law-clinic.

41 Zie https://www.vbk.nl/.

42 Dit is ook een van de vier componenten van Rests Four Component Model voor ethisch handelen, naast morele beoordeling, morele motivatie en moreel karakter. Zie Rest \& Narváez, 1994. 
morele vraag); afweging (van het gewicht van de argumenten en van de daaruit voortvloeiende handelingsmogelijkheden); om ten slotte tot een aanpak te komen.

Het 'Utrechts stappenplan' sluit in zekere zin aan op het voor rechtenstudenten vertrouwde casus oplossen. Het is daarom een interessante methode, zeker ook als manier om juridische en morele vragen en overwegingen te vergelijken: waarin verschillen zij en waar liggen zij in elkaars verlengde, in een professionele praktijk en daarbuiten? De vraag wie betrokken zijn bij de morele vraag en hun perspectief kan bijvoorbeeld professioneel-ethisch bijzonder belangrijk zijn voor de begrenzing van de partijdigheid van een advocaat of juist de onpartijdigheid van een notaris. Dit terwijl dat - afgezien wellicht van het tuchtrecht - niet als relevant geldt voor de strikt juridische oplossing van de casus.

De tweede methode is het moreel beraad, afkomstig van VUmc (Amsterdam). ${ }^{44}$ Dit is een ethische interventie die is gericht op het verbeteren van de zorgpraktijk door het bevorderen van reflectie bij de betrokkenen (zie Bree \& Veening, 2017). Het moreel beraad lijkt op het Utrechtse stappenplan, maar betrekt daarin nadrukkelijk de vraag wie er moet beslissen en hoe degenen die het moreel beraad voeren, zich voelen over die conclusie. De methode van het moreel beraad lijkt bovendien de nadruk te leggen op een casus die een van de deelnemers zelf heeft meegemaakt. Hoewel dit zinnig lijkt vanwege de persoonlijke betrokkenheid bij een reëel probleem, is de bruikbaarheid daardoor beperkter voor (professioneel) ethiekonderwijs aan de universiteit. Voor studentstagiaires kan een moreel beraad over een eigen stage-ervaring nuttig zijn. Uiteraard kan er ook aangesloten worden bij de studeerpraktijk van studenten, bijvoorbeeld ten aanzien van samenwerkingsproblemen of (vermoedens van) fraude. De inzet van een docent als gespreksleider is problematisch omdat dat de noodzakelijke open en onderzoekende houding van de deelnemers aan het moreel beraad kan belemmeren.

De derde methode is een specifieke methode van het moreel beraad, de dilemmamethode, waarbij het draait om dialogische uitwisseling van perspectieven. Deze perspectieven zijn gebaseerd op waarden en normen. Ze moeten een uitweg bieden voor een moreel probleem dat nadrukkelijk als moreel dilemma wordt geformuleerd (zie Graste, 2009: 43-62). Interessant aan deze methode is dat waarden en normen een belangrijke rol spelen, waardoor zowel juridisch-ethische, professioneel-juridische als persoonlijke waarden en normen kunnen worden ingebracht. Hoe aantrekkelijk deze methoden voor ethiekonderwijs aan rechtenstudenten ook kunnen zijn, we kunnen er kanttekeningen bij plaatsen dat deze methoden slechts een structuur bieden voor ethische reflectie. De competenties van de gespreksleider zijn belangrijk, maar vormen geen waarborg voor de kwaliteit van de inhoud van de morele reflectie (Bolt, 2010: 17).

Interessant is verder het door Gross-Schaefer ontwikkelde principles-based ethical decision model. Dit is een juridische variant van eerder genoemde beslismo-

44 Deze methode is uitvoerig beschreven in en ingevoerd door Widdershoven, 2010. Gespreksmethode ter structurering: meerdere methodes mogelijk. Zie Manschot \& Van Dartel, 2003. 
dellen, die past bij de waarden van het recht. Gross-Schaefer biedt een ethisch beslissingsmodel om ethische dilemma's mee op te lossen in acht stappen:

1 Definieer het probleem en zorg ervoor dat alle relevante feiten worden verzameld.

2 Noteer professionele normen/standaarden, wetten en voorschriften die relevant zijn voor de situatie.

3 Noteer alle partijen die relevant zijn voor besluitvorming (stakeholders).

4 Maak een lijst van alle persoonlijke en werkgerelateerde waarden die bij de beslissing betrokken zijn.

5 Maak een lijst met alle mogelijke alternatieve acties.

6 Kies en stel prioriteiten (regels, partijen, waarden, professionele normen/standaarden).

7 Maak een beslissing op basis van de prioriteiten.

8 Bedenk een strategie die uw beslissing effectief zal implementeren (Gross-Schaefer, 2018).

Als laatste methode, die overeenkomsten vertoont met 'het reflectieve equilibrium' als filosofische methode, wijzen we op een stappenplan, dat gebruikt wordt in een vak voor eerstejaars honours-studenten. ${ }^{45}$ In dat vak komt onder meer aan de orde: hoe kunnen we rechtvaardigheid begrijpen (in de context van het recht) en wat betekent rechtvaardigheid voor ons als persoon en jurist? ${ }^{46}$ Voor de gedachtevorming over deze vragen worden vijf denkstappen gehanteerd:

1 We hebben een intuïtieve overtuiging: dit is (on)rechtvaardig!

2 Welk principe (van rechtvaardigheid) ligt ten grondslag aan deze overtuiging?

3 Hoe kunnen we dit principe beter begrijpen: theorie?

4 Twijfel: zijn er andere principes en theorieën die overtuigend(er) zijn?

5 Bevestiging of heroverweging van het intuïtieve standpunt, beter beargumenteerd.

De gebruikte theorieën sluiten aan bij de centrale tradities in moreel redeneren. ${ }^{47}$ De bedoeling is dat ook andere manieren van gestructureerde, morele gespreksvoering worden uitgeprobeerd in Utrecht en dat technieken van kritisch denken als relevant aspect van moreel redeneren explicieter aandacht krijgen.

\subsection{Afrondende opmerkingen: effectieve onderwijsmethoden}

Onderzoek toont aan dat een pedagogiek op basis van contextuele, rijke, emotioneel boeiende, op rollen gebaseerde probleemoplossing, gekoppeld aan een voortdurend reflectief discours, waarschijnlijk een significante verbetering zal opleveren van de effectieve betrokkenheid van rechtenstudenten bij (en beheersing van de rol van) ethisch beroepsbeoefenaar (Lerner, 2004: 643 e.v.). Onderzoek naar het leren ours-variant van het vak Perspectieven op recht wordt gebruikt: Sandel, 2010 (14de druk 2018: 3637).

47 Zoals het utilisme van Mill, een aantal theorieën die vrijheid benadrukken, waaronder Kants deontologie, aangevuld met Rawls' principes van vrijheid en gelijkheid, alsook de deugdethiek van Aristoteles. 
van volwassenen/studenten en morele ontwikkeling pleit voor een op ervaring gerichte benadering. Idealiter worden cursussen over professionele verantwoordelijkheid gekoppeld aan stages in de praktijk, en worden ethische kwesties geïntegreerd in het curriculum (Rhode, 2009: 43 e.v.). Belangrijk is wel te benadrukken dat experiential learning zonder morele dialoog geen invloed heeft op morele redeneervaardigheden. Het gebruik van didactiek die live-cliënt of gesimuleerd leren combineert met regelmatige gelegenheid voor kritisch reflectief gesprek en schrijven over ethische kwesties, kan de universiteit studenten ertoe brengen dieper na te denken over ethische dilemma's (Lerman, 1998: 457 e.v.). In onderwijssessies zou over actuele morele dilemma's binnen de juridische beroepspraktijk nagedacht kunnen worden. ${ }^{48}$ Discussies over morele dilemma's blijken een effectieve interventie te zijn voor het niveau van moreel redeneren (en van ethische oordeelsvorming). Hier alleen college over geven heeft weinig effect, het gaat erom wat studenten doen wat daarvoor belangrijk is (Ferris, 2015: 194). ${ }^{49}$

\section{Toetsing}

Niet alleen de leerdoelen en de onderwijsmaterialen/opdrachten, maar ook de toetsing dient uitgelijnd te zijn (constructive alignment) (Biggs \& Tang, 2011). Toetsing is een zeer krachtige initiator voor leren. De gebruikelijke toetsing leidt vaak tot een beperkte benadering van professionele ethiek, bijvoorbeeld kennis van de gedragsregels en de toepassing ervan op een casus. Het concept van ethisch-passend handelen toetsen is complexer. Het toetsen van 'een goed moreel karakter' in een context van vrije academische gedachtewisseling is onacceptabel als leerresultaat; de algemene competentie die kan worden getoetst is volgens Robertson genuine, thorough and thoughtful engagement met vragen van morele complexiteit in de juridische werkelijkheid. Hij stelt dat verscheidene toetsingselementen van ethiek, zowel formatief als summatief, door het gehele curriculum heen nodig zijn (Robertson, 2009: 74-75).

Een interessant startpunt voor differentiatie in toetsen is de door Campbell e.a. ontwikkelde 'know-can-do'-leerpiramide. Volgens deze piramide kan op het gebied van (medische) ethiekonderwijs een opbouw worden aangebracht van kennis, naar het bezitten van bepaalde vaardigheden (selecteren en toepassen kennis van het kennisniveau), naar handelen in actuele praktijk boven in de piramide. Kennis is nodig voor gewenning, om de vorm waarin een leerling zich gedraagt vorm te geven, zodat er een handeling ontstaat die klinisch passend en effectief is. Bij deze drie onderdelen horen ook specifieke uitkomsten. Bij kennis is dat kennis en begrip van ethische beginselen, medische richtlijnen en historische precedenten. Bij gewenning is dat kritisch denken, ethisch bewustzijn en empathie, en bij actie/handelen is dat klinisch-ethische competentie. Hierbij worden door Campbell e.a. di- 
verse toetsmethoden gesuggereerd..$^{50}$ Rogers past de methode ontwikkeld door Campbell e.a. vervolgens ook toe op (professioneel) ethisch onderwijs voor juristen (Rogers, 2010: 220 e.v.). Afhankelijk van het niveau/doel van het ethisch onderwijs in het curriculum kan daarom aansluiting worden gezocht bij diverse (creatieve) wijzen van toetsing. Het model kan als handige tool worden gebruikt voor juristen om andere wijzen van toetsing dan enkel de op kennis gebaseerde toetsing te overwegen. Het is immers van belang dat de wijze van toetsing goed is afgestemd op de doelen en de wijzen van onderwijs, om zo deep-learning bij studenten te bevorderen. Bovendien nodigt onze bredere 'judgement' approach uit tot hogere niveaus (van leren, maar ook van de zojuist besproken piramide) dan enkel het kennisniveau. Het uitsluitend toevoegen van kennisvragen over ethiek aan tentamens is daarom onvoldoende.

We lichten hier enkele voorbeelden uit van relevante en soms ook creatieve toetsing van het Utrechtse ethiekonderwijs. Eerstejaarsstudenten wordt in meta-juridische papers nadrukkelijk gevraagd om te beargumenteren waarom een door henzelf gekozen theorie over recht, respectievelijk (in geval van honoursstudenten) rechtvaardigheid, beter is dan andere theorieën in een denkbeeldige casus of in een actueel maatschappelijk probleem. In de (vaak door uitwisselingsstudenten gevolgde keuze) cursus Legal Ethics (vanaf 2021 Law \& Ethics) maken studenten zelf een filmpje (intervisie) op basis van dilemma's (van iemand uit een juridische professie). Zo'n filmpje heeft veel weg van het in de literatuur beschreven storyboard-idee en haakt aan bij het idee van de narratives. In het simulatiespel voor derdejaars honours-rechtenstudenten maakt een ethische reflectie deel uit van het te schrijven beroepsproduct (zoals een adviesbrief, akte, besluit of requisitoir).

\section{Conclusie}

In deze bijdrage hebben wij het belang van het opnemen van (professionele ethiek) in het curriculum benadrukt. Inhoudelijke aanknopingspunten voor de integratie van professionele ethiek in de academische juridische opleiding gaan verder dan het leren van gedragsregels alleen, wat ook voornamelijk in de postacademische opleidingen aan bod komt, terwijl de (kritisch-)ethische reflectie (op de professionele rol) juist eerder begint en dient te worden gestimuleerd. Juist voor jongvolwassenen is dat tijdig. Goed opgestelde curricula, en breder onderwijs, kunnen significant bijdragen aan de ontwikkeling van moreel redeneren. In deze bijdrage hebben we diverse inhoudelijke aanknopingspunten besproken voor onderwijs. Deze aanknopingspunten vragen om een curriculum brede inbedding, van algemeen ethische theorieën in rechtstheoretische vakken, naar moraal in recht in rewenning/vaardigheidsniveau case reports (gebaseerd op door studenten zelf geïdentificeerde zaken), portfolio's en case vignettes (met behulp van hypothetische zaken), en handelingsniveau de Objective Structured Clinical Examination-methode (OSCE) en de 360 graden-feedback. Zie Campbell, Chin \& Voo, 2007: 431-436. Wong \& Cheung, 2003: 5-8 plaatsen case reports bij de toetsvormen op kennisniveau, en de OSCE als toetsvorm bij het niveau van toepassing met de geschikte vaardigheden. 
guliere vakken en in professionele ethiek later in het curriculum. Dit dient stapsgewijs te gebeuren. Dit onderwijs dient idealiter een combinatie te zijn van losse vakken specifiek over beroeps- of professionele ethiek, positiefrechtelijke vakken met ethische elementen en klinische training, in de vorm van een educational continuum. Idealiter focussen deze niet enkel op professionele regels of ethische dilemma's, maar ook op ethiek als onderdeel van het maken van ethische oordeelsvorming.

Dit artikel bespreekt diverse (juridische en niet-juridische) methoden die kunnen worden gebruikt om het onderwijs vorm te geven. Actieve participatie, reflectie en - idealiter - eigen ervaringen zijn daarbij van groot belang. Learning bij doing draagt bij aan morele oordeelsvorming. Klinische cursussen zijn het meest effectief, aangezien daarin zowel verantwoordelijkheid voor anderen in de maatschappij alsook het maken van echte onomkeerbare, ethische keuzes zijn betrokken. Reeds verricht onderzoek pleit voor een benadering die is gericht op ervaringen (een zogenaamde experiential approach). Helaas zijn klinische cursussen maar in beperkte mate mogelijk in het huidige, juridische curriculum. Deze ontwikkeling zal zich dan ook noodzakelijkerwijs in de praktijk verder moeten ontwikkelen. Een aantal modellen uit niet-juridische disciplines kan behulpzaam zijn bij het bieden van structuur voor ethische reflectie, voor zover het morele sensitiviteit en morele oordeelsvorming stimuleert. Het gebruik van narratieven en rolmodellen heeft ook potentie en pleit juist voor academici die ook in de praktijk hebben gewerkt. In Utrecht zijn we op dit moment diverse onderwijsvormen en methoden aan het uitproberen die zijn gericht op het herkennen van morele kwesties en morele oordeelsvorming. Toetsing is een zeer krachtige initiator voor leren. Verscheidene elementen die ethiek toetsen, zowel formatief als summatief, zijn nodig door het curriculum heen. Leeractiviteiten en toetsing kunnen worden opgebouwd in het curriculum van kennis, naar competentie van bepaalde vaardigheden, en ten slotte naar (ethisch) handelen. Goede afstemming tussen niveaus en toetsvormen is daarbij nodig in verband met constructive alignment, om zo deep-learning te bevorderen.

\section{Literatuur}

Ahsmann, M. J. A. M. (2016). De juridische opleiding en de T-shaped lawyer: hoe leiden universiteiten goede juristen op? In De kwaliteit binnen het notariaat (pp. 7-25). Deventer: Wolters Kluwer.

Bauw, E. e.a. (2019). Togadragers in de Rechtsstaat, De juridische professies en de toegang tot het recht, Den Haag: Boom juridisch 2019.

Becker, M. (2018). Integriteit in het Openbaar bestuur. Juristen moeten hun hand niet overspelen. NJB 2018, 1427-1430.

Bensinger-Liebman, C. (1995). The Profession of Law: Columbia Law School's Use of Experiential Learning Techniques to Teach Professional Responsibility. Law and Contemporary Problems, 58(3/4), 73-86.

Biggs, J. \& Tang, C. (2011). Teaching for Quality Learning at University. What the Student Does. Maidenhead.

Bolt, I. e.a. (2015). To Dispense or Not to Dispense? Ethical Case Decision-Making in Pharmacy Practice. International Journal of Clinical Pharmacy, 37(6), 978-981. 
Bolt, L. L. E. (2010). Het stappenplan: een structuur van ethische reflectie en discussie. In L. L. E. Bolt, M. F. Verwey \& J. J. M. van Delden (Red.), Ethiek in praktijk (pp. 17-32). Assen: Koninklijke Van Gorkum 2010, p. 17-32.

Boon, A. (2002). Ethics in Legal Education and Training: Four Reports, Three Jurisdictions and a Prospectus. Legal Ethics, 5(1), 34-67.

Bree, M. \& Veening, E. P. (2017). Handleiding Moreel Beraad. Praktische gids voor zorgprofessionals. Assen: Koninklijke Van Gorcum.

Bundy, S. (1995). Ethics Education in the First Year: An Experiment. Law and Contemporary, 58(3), 19-35.

Burg, W. van der (1997). The Importance of Ideals. The Journal of Value Inquiry, 31(1), 23-37.

Burg, W. van der (2010). Law and Ethics: The Twin Disciplines. Erasmus Working Paper Series on Jurisprudence and Socio-Legal Studies, no. 10-2.

Burns, R. P. (1996). Legal Ethics in Preparation for Law Practice. Nebraska Law Review, 75(4), 684-703.

Campbell, A. V., Chin, J., \& Voo, T.-Ch. (2007). How Can We Know that Ethics Education Produces Ethical Doctors? Medical Teacher, 29(5), 431-436.

Chapman, J. (2002). Why Teach Legal Ethics to Undergraduates? Legal Ethics, 5(1-2), 68-89.

Collbran, S. \& Gilding, A. (2014). Exploring Legal Ethics Using Student Generated Storyboards. The Law Teacher, 48(3), 296-320.

Cottrell, S. (2017). Critical Thinking Skills, Developing Effective Argument and Analysis. Londen: Palgrave MacMillan.

Dijk, E. W. J. van (2018). Deurwaarders en Ethiek. Tijdschrift voor de Procespraktijk, 4, 99107.

Domselaar, I. van (2017). Een eerlijke deal? Over ethisch minimalisme in de corporate advocatuur. Ars Aequi, 66(11), 902-910.

Domselaar, I. van (2020). Professionele identiteit en beroepsethiek voor advocaten. Pleidooi voor (meer) realisme. NJB 2020/2975.

Duncan, N. J. (2015). A Future for Legal Education: Personal and Professional Development and Ethics. Nottingham Law Journal, 24, 67-78.

Dworkin, R. (1977). Taking Rights Seriously. Cambridge, Mass.: Harvard University Press; herdr. Londen: Bloomsbury 2013.

Edwards, H. T. (1992). The Growing Disjunction between Legal Education and the Legal Profession. Michigan Law Review, 91(1), 34-78.

Elkins, J. R. (1986). Symposium on Legal Education and the Pedagogy of Ethics. A Conversation Called Ethics. Legal Studies Forum X, 10(3), 265-274.

Ferris, G. (2015). Uses of Value in Legal Education. Cambridge: Intersentia.

Fogteloo M. \& Smolders, A. (2021). De butlers van de Zuidas. Bedrijfsadvocaten en ethiek. De Groene Amsterdammer, 145(8), 28-35.

Fogteloo, M. \& Smolders, A. (2020). Rambo's met aktetas. Strafpleiters en ethiek. De Groene Amsterdammer, 144(37), 22-29.

Frank, J. (2009). Law and the Modern Mind. New Brunswick: Transaction Publishers (1931).

Gentile, M. C. (2010). Giving Voice to Values: How to Speak Your Mind When You Know What's Right. New Haven, CT: Yale University Press.

Gilligan, C. (1982). In a Different Voice. Psychological Theory and Women's Development. Cambridge: Harvard University Press.

Graste, J. (2009). Omgaan met dilemma's. Een methode voor ethische reflectie. In H. Manschot \& H. van Dartel (Red.), In gesprek over goede zorg. Overlegmethoden voor ethiek in de praktijk (pp. 43-62). Amsterdam: Boom.

Green, B. A. (1998). Less Is More: Teaching Legal Ethics in Context. William \& Mary Law Review, 39(2), 357-392.

Gribnau, J. L. M. (2017). Belastingen, ethiek en waarden. Een weerbarstig driespan. Nederlands Tijdschrift voor Fiscaal Recht, 2017/660, 1-7. 
Groot-van Leeuwen, L. E. de \& Schuyt, C. J. M. (1992). Morele redeneerpatronen bij advocaten. In P. de Bok e.a. (Red.), Wat de advocaat betaamt (pp. 71-90). Zwolle: W.E.J. Tjeenk Willink.

Gross-Schaefer, A. (2018). Legal Ethics Education: From Academic Foundation through Professional Practice. Professional Lawyer, 25(1), 18-42.

Hart, H. L. A. (2012). The Concept of Law. Oxford: Oxford University Press (1961).

Hartwell, S. (1995). Promoting Moral Development Through Experiential Teaching. Clinical Law Review, 1(3), 505-540.

Heineman, B. W., Lee, W. F. \& Wilkins, D. B. (2014). Lawyers as Professionals and as Citizens: Key Roles and Responsibilities in the 21st Century. Center on the Legal Profession at Harvard Law School.

Holmes, O. W. (1897). The Path of the Law. Harvard Law Review, 457-478.

Huijgen, W. G. (2017). Notariaat en integriteit in de registergoederenpraktijk. WPNR 2017/7159, 545-550.

Kaptein, H. J. R. (2006). Kwade Zaken? De Moraal van het Juridisch Beroep. Nijmegen: Ars Aequi.

Klink, B. van, Vries, B. de \& Bleeker, T. (2017). Recht in context. Naar een brede academische vorming van juristen. NJB, 92(14), 916-922.

Kolb, D. A. (1984). Experiential Learning: Experience as the Source of Learning and Development. Englewood Cliffs, NJ: Prentice Hall.

Kupfer, S. (1996). Authentic Legal Practices. Georgetown Journal of Legal Ethics, 10(1), 33114.

Lerman, L. G. (1998). Teaching Moral Perception and Moral Judgment in Legal Ethics Courses: A Dialogue about Goals. William \& Mary Law Review, 39(2), 457-488.

Lerner, A. M. (2004). Using Our Brains: What Cognitive Science and Social Psychology Teach Us About Teaching Law Students To Make Ethical, Professionally Responsible Choices. QLR, 23(3), 643-706.

Loth, M. (2011). Naar een betere beroepsethiek. De publieke verantwoordelijkheid van de advocatuur. Advocatenblad, 26 juni 2011.

Loth, M. A. \& Gaakeer, A. M. P. (2017). Praktijkvaardigheden. Ethiek en het juridisch beroep. Den Haag: Boom.

Mackor, A. R. (2014). Kernwaarden: nuttig of nonsens? Rechterlijke macht: geschraagd of ondermijnd door kernwaarden? RM Themis 2014-1, 6-9.

Mak, E. (2017). The T-shaped Lawyer and Beyond: Rethinking Legal Professionalism and Legal Education for Contemporary Societies. Den Haag: Eleven International Publishing.

Manschot, H. \& Dartel, H. van (2003). In gesprek over goede zorg. Amsterdam: Boom.

Meijer, M. de (2019). Focus op de integriteit van het Openbaar Ministerie. Ars Aequi, 12, 946-956.

Menkel-Meadow, C. J. (1991). Can a Law Teacher Avoid Teaching Legal Ethics? Journal of Legal Education, 41(1), 3-10.

Mertens, T. (2012). Mens en mensenrechten, Basisboek Rechtsfilosofie. Amsterdam: Boom.

Miller, J. M. (2005). Legal Ethics and Classroom Teaching: The Apology Symposium. Widener Law Journal; Widener Commonwealth Law Review, 14(2), 365-436.

Moliterno, J. E. (1991). An Analysis of Ethics Teaching in Law Schools: Replacing Lost Benefits of the Apprentice System in the Academic Atmosphere. University of Cincinnati Law Review, 60, 83-134.

Moliterno, J. E. (1996). On the Future of Integration between Skills and Ethics Teaching: Clinical Legal Education in the Year 2010. Journal of Legal Education, 46(1), 67-78.

Morgan, T. D. (1998). Use of the Problem Method for Teaching Legal Ethics. William \& Mary Law Review, 39(2), 409-419.

Nicholson, D. (2010). Learning in Justice: Ethical Education in an Extra-Curricular Law Clinic. In M. Robertson e.a. (Eds.), The Ethics Project in Legal Education. Londen: Routledge. 
Nicolae, M. (2015). Legal Education, Legal Practice and Ethics. Legal Education Review, 25(1), 237-250.

Niemeijer, E. \& Voert, M. ter (2005). Vertrouwen onder druk. Vrije juridische beroepen tussen professie en commercie. Justitiële Verkenningen, 31(3), 9-31.

Noordegraaff, M. \& Siderius, K. (2016). Perspectieven op publieke professionaliteit. M\&O, 2, 4-19.

Ogden, G. L. (1984). The Problem Method in Legal Education. Journal of Legal Education, 34(4), 654-673.

Oostrom-Streep, N. C. van (2010). Tussen Scylla en Charybdis. Op zoek naar koers en waarde voor het juridisch onderwijs (oratie Utrecht). Apeldoorn/Antwerpen: Maklu Uitgevers.

Pearce, R. G. (1998). Teaching Ethics Seriously: Legal Ethics as the Most Important Subject in Law School. Loy.U., 29, 719-739.

Pitel, S. G. A. (2005). The Teaching of Legal Ethics: Recent Developments in Ontario. Journal of Legal Education, 55(4), 592-59.

Radbruch, G. (1946). Gesetzliches unrecht und übergesetzliches Recht. Süddeutsche Juristenzeitung, 105-108.

Rest, J. R. \& Narváez, D. (1994). Moral Development in the Professions: Psychology and Applied Ethics. Hillsdale, NJ: Lawrence Erlbaum.

Rest, J. R. e.a. (1986). Moral Development: Advances in Research and Theory. New York, NY: Praeger.

Rest, J. R. e.a. (1999). DIT2: Devising and Testing a Revised Instrument of Moral Judgment. Journal of Educational Psychology, 91(4), 644-659.

Rhode, D. L. (1992). Ethics by the Pervasive Method. Journal of Legal Education, 42(1), 3156.

Rhode, D. L. (2003). If Integrity is the Answer, What Is the Question? Fordham Law Review, 72(2), 333-344.

Rhode, D. L. (2007). Teaching Legal Ethics. Saint Louis University Law Journal, 51(4), 10431058.

Rhode, D. L. (2009). Legal Ethics in Legal Education. Clinical L. Rev., 16, 43-56.

Robertson, M. (2004). Renewing a Focus on Ethics in Legal Education. Paper presented at the Australian Lawyers and Social Change Conference, Canberra, Australia.

Robertson, M. (2005). Challenges in the Design of Legal Ethics Learning Systems. Legal Ethics, 8(2), 237-239.

Robertson, M. (2009). Providing Ethics Learning Opportunities Throughout the Legal Curriculum. Legal Ethics, 12(1), 61-78.

Rogers, J. (2010). 11. Coming to Terms with Legal Ethics Assessment. In M. Robertson e.a. (Eds.), The Ethics Project in Legal Education (pp. 212-230). New York/Londen: Routledge.

Sandel, M. J. (2009 (2018)). Rechtvaardigheid. Wat is de juiste keuze? Utrecht: Uitgeverij Ten Have (Justice; What Is the Right Thing to Do?; vertaald door D. Lagrand).

Schrag, P. G. (2009). Teaching Legal Ethics through Role Playing. Legal Ethics, 12(1), 35-58.

Soeharno, J. E. (2014). Kernwaarden: nuttig of nonsens? I. Kernwaarden. Een erekwestie. RM Themis 2014-1, 2-6.

Taekema, S. \& Burg, W. van der (2020). Legal Philosophy as an Enrichment of Doctrinal Research Part I: Introducing Three Philosophical Methods. Law \& Method, 1-19.

Watson, A. S. (1975). Lawyers and Professionalism: A Further Psychiatric Perspective on Legal Education. University of Michigan Journal of Law Reform, 8, 248-285.

Widdershoven, G. (2010). Reflectie als interventie (oratie Amsterdam VU).

Witteveen, W., Klink, B. van \& Been, W. de (2002). De sociale rechtsstaat voorbij: twee ontwerpen voor de huis van de rechtsstaat. Den Haag: Sdu Uitgevers.

Wolff, D. de (2018). Het belang van een goede rechtsbedeling (oratie Amsterdam UvA, no. 590).

Wolff, D. de (2020). Kernwaarden van de Advocatuur. Deventer: Wolters Kluwer. 
Professionele ethiek in het academisch juridisch onderwijs - Enige inhoudelijke en didactische aanknopingspunten

Wong, J. G. W. S. \& Cheung, E. P. T. (2003). Ethics Assessment in Medical Students. Medical Teacher, 25(1), 5-8. 